DOI: http://dx.doi.org/10.1590/1678-457X.6370

\title{
Replacement of mechanically deboned chicken meat with its protein hydrolysate in mortadella-type sausages \\ Carlos Pasqualin CAVALHEIRO ${ }^{1 *}$, Fernanda Luisa LÜDTKE ${ }^{1}$, Flávia Santi STEFANELLO', Ernesto Hashime KUBOTA ${ }^{1}$, Nelcindo Nascimento TERRA ${ }^{1}$, Leadir Lucy Martins FRIES ${ }^{1}$
}

\begin{abstract}
Mortadella-type sausage manufactured using mechanically deboned chicken meat were reformulated replacing MDCM with increasing amounts of MDCM protein hydrolysates (10\%, 20\%, and 30\%), and their physicochemical, microbiological, and sensorial characteristics were evaluated for 60 days of storage at $4{ }^{\circ} \mathrm{C}$. The higher substitutions resulted in sausages more susceptible to lipid oxidation with higher TBARS values during storage; however, these values were lower than the organoleptic perception threshold. The sausages were darker and less red, with lower lightness $\left(L^{*}\right)$ and redness $\left(a^{*}\right)$ values than those of the control treatment. They had soft texture, which was evidenced by both the instrumental and sensory analysis. Therefore, the formulation containing $10 \%$ of MDCM protein hydrolysates proved to be the most suitable for mortadella-type sausage elaboration.
\end{abstract}

Keywords: protein hydrolysates; mortadella-type sausage; mechanically deboned chicken meat; TBARS; texture properties.

\section{Introduction}

Mechanically deboned chicken meat (MDCM) is a commonly ingredient used in the formulation of cooked meat products. According to the Brazilian legislation, it is possible to use up to $60 \%$ of MDCM in cooked meat sausages (Brasil, 2000). However, there may be some drawbacks to the use of this kind of meat as raw material such as a rapid onset of oxidation resulting in off-flavors and off-odors in the final product (Mielnik et al., 2002).

Protein hydrolysates may possess physicochemical characteristics and bioactivities not found in the original proteins, such as antioxidant activity and higher water-holding capacity (Cumby et al., 2008). The generated peptides could inhibit the harmful changes induced by lipid oxidation due to the presence of certain amino acid residues, such as tyrosine, methionine, histidine, tryptophan, and proline. Several studies have demonstrated the antioxidant potential of protein hydrolysates from many raw materials, such as potato (Wang \& Xiong, 2005), whey (Contreras et al., 2011), soy (Peña-Ramos \& Xiong, 2003), fish (Dekkers et al., 2011), and shrimp waste (Dey \& Dora, 2014). Furthermore, a study has shown that shrimp shell hydrolysates can inhibit human cancer cell proliferation (Kannan et al., 2011).

Studies involving the use of meat protein hydrolysates in meat products are still scarce. Some studies have been carried out using non-meat as raw materials such as soy, potato, and dairy proteins. However, the use of MDCM, which is an ingredient commonly used by the meat industry, has not been studied yet. Thus, the aim of this study was to produce mortadella-type sausages with increasing amounts (10\%, 20\%, and $30 \%$ ) of MDCM protein hydrolysate replacing MDCM and to analyze its effect on product properties during storage at $4{ }^{\circ} \mathrm{C}$ for $60 \mathrm{~d}$.

\section{Materials and methods}

\subsection{Production of MDCM protein hydrolysate}

Previous tests have been carried out to define the best time and temperature conditions for the hydrolysis process. After thawing overnight in a cold room $\left(4^{\circ} \mathrm{C}\right), 250 \mathrm{~g}$ of $\mathrm{MDCM}$ were minced using a cutter (G. Paniz, Caxias do Sul, Brazil) and mixed with distilled water in the ratio of $1: 2(\mathrm{w} / \mathrm{v})$. Then, $1 \mathrm{~mL}\left(0.4 \%\right.$ in relation to the meat amount) of the Alcalase ${ }^{\circledR}$ 2.4 L enzyme (Novozymes, Bagsvaerd, Denmark) was added, and the mixture was held at $60^{\circ} \mathrm{C}$ for $60 \mathrm{~min}$ in a water bath (Marconi, Piracicaba, Brazil). The $\mathrm{pH}$ was not adjusted during the hydrolysis process with the purpose to keep the original MDCM $\mathrm{pH}$. The hydrolysis reaction was finished by placing the mixtures in boiling water for $15 \mathrm{~min}$. The degree of hydrolysis was calculated according to Hoyle \& Merritt (1994), and the value obtained was $14.38 \%$. The proximate composition of MDCM protein hydrolysates was: $87.61 \%$ of moisture, $4.37 \%$ of protein, $7.68 \%$ of fat and, $0.34 \%$ of ashes. The MDCM protein hydrolysates were not subjected to any drying process or fat content removal.

\subsection{Mortadella-type sausage elaboration}

Each batch of mortadella-type sausages was formulated with different amounts of MDCM protein hydrolysate as follows: $0 \%$ (CT); 10\% (T1); 20\% (T2); and 30\% (T3). The other ingredients were used according to a typical Brazilian formula as follows:

Received 28 Apr., 2014

Accepted 25 June, 2014 (006370)

${ }^{1}$ Programa de Pós-Graduação em Ciência e Tecnologia dos Alimentos, Universidade Federal de Santa Maria - UFSM, Santa Maria, RS, Brasil,

e-mail: carlos.cavalheiro@mail.ufsm.br

${ }^{*}$ Corresponding author 
MDCM (CT - 60\%; T1 - 50\%; T2 - 40\%; T3 - 30\%), pork meat (30\%), pork fat (10\%), ice/water (CT - 29\%; T1 - 26.14\%; T2 - 23.27\%; T3 - 20.22\%), salt (1.9\%), cassava starch (5\%), isolated soy protein $(2 \%)$, spices $(1 \%)$, sodium nitrate/nitrite $(0.35 \%)$, sodium erythorbate $(0.25 \%)$, and black pepper $(0.1 \%)$. The amount of ingredients was determined based on the amount of meat. Due to the high moisture level of the MDCM protein hydrolysate, the ice/water amount added to the mortadella-type sausages was adjusted. The mass was stuffed using $80-\mathrm{mm}$ diameter water-impermeable plastic casings in pieces with approximately $300 \mathrm{~g}$. The sausages were cooked at $80{ }^{\circ} \mathrm{C}$ for $90 \mathrm{~min}$, until reaching a core temperature of $72^{\circ} \mathrm{C}$. Afterwards, they were cooled under running water and stored at $4{ }^{\circ} \mathrm{C}$.

\subsection{Physicochemical analyses}

\section{Proximate composition}

Moisture, protein (total nitrogen), and ash analyses were carried out according to Association of Official Analytical Chemists (1997). Total fat was extracted according to the method proposed by Bligh \& Dyer (1959), and carbohydrates were calculated from the difference. The energy value (kcal) was calculated using the values corresponding to fat $(9 \mathrm{kcal} / \mathrm{g})$, protein $(4 \mathrm{kcal} / \mathrm{g})$, and carbohydrates $(4 \mathrm{kcal} / \mathrm{g})$.

\section{TBARS}

Lipid oxidation was assessed using the thiobarbituric acid reactive substances' (TBARS) method (Raharjo et al., 1992). TBARS were calculated and expressed as mg malonaldehyde (MDA) per kg of sausage.

\section{Color parameters}

The determination of CIE $L^{\star} a^{\star} b^{\star}$ color parameters was performed using a Chroma Meter CR-300 (Minolta Camera Co. LTD, Osaka, Japan). The color parameters were also converted into Chroma $\left(C^{\star}\right)$ and hue angle $\left(h^{\circ}\right)$.

\section{Texture profile analysis}

Texture profile analysis (TPA) was performed using a TA-XT.plus Texture Analyzer and a Texture Expert Exponent Software (Stable Micro Systems Ltd., Surrey, England) in a double compression cycle test according to Bourne (1978). The textural attributes calculated were hardness, springiness, cohesiveness, gumminess, and chewiness.

\subsection{Microbiological analysis}

Two sausages per batch were used to evaluate the microbiological characteristics according to the method described by Vanderzant \& Splittstoesser (1992). The Total viable counts (TVC), lactic acid bacteria (LAB), Enterobacteriaceae, Escherichia coli, Staphylococcus aureus, Salmonella, and sulfite reducing clostridia were analyzed.

\subsection{Sensory analysis}

This study protocol was approved by the Ethics in Research Committee of The Federal University of Santa Maria under the number 01228612.6.0000.5346. The sensory parameters evaluated were color, aroma, taste, texture, and appearance using a seven-point scale, and purchase intention in a five-point scale (Meilgaard et al., 1999).

\subsection{Statistical analysis}

Proximate composition analysis was performed in triplicate; TBARS and color analyses were performed in quintuplicate; texture profile analysis was performed in nine replicates; microbiological analysis was performed in quadruplicate, and 52 untrained panelists performed the sensorial analysis. The entire experiment was conducted twice. Data were analyzed using the statistical package SPSS 17.0. A completely randomized experimental design with four levels of MDCM protein hydrolysate $(0,10,20$, and 30\%) was used. Analyses of variance (ANOVA) were performed with confidence interval of 95\%, followed by the post-hoc Tukey test to establish statistical differences between treatments.

\section{Results and discussion}

\subsection{Proximate composition}

Mortadella-type formulations differed in moisture, protein, fat, ash and, calorific value levels $(\mathrm{P}<0.05$, Table 1$)$. The moisture content of the sausages made with MDCM protein hydrolysate was between 65.41 and $66.98 \%$, and it was

Table 1. Proximate composition (g/100g) and energy value (kcal/100g) of mortadella-type sausages produced with different levels of MDCM protein hydrolysates ${ }^{1}$.

\begin{tabular}{|c|c|c|c|c|}
\hline & \multicolumn{4}{|c|}{ Treatments $^{2}$} \\
\hline & $\mathrm{CT}$ & $\mathrm{T} 1$ & $\mathrm{~T} 2$ & $\mathrm{~T} 3$ \\
\hline Moisture & $68.21 \pm 0.10^{\mathrm{a}}$ & $66.98 \pm 0.25^{b}$ & $65.41 \pm 0.17^{c}$ & $65.41 \pm 0.07^{c}$ \\
\hline Protein & $10.63 \pm 0.33^{c}$ & $11.09 \pm 0.52^{b c}$ & $12.00 \pm 0.20^{\mathrm{a}}$ & $11.49 \pm 0.09^{\mathrm{ab}}$ \\
\hline Fat & $10.66 \pm 0.33^{b}$ & $10.41 \pm 0.36^{b}$ & $11.71 \pm 0.09^{\mathrm{a}}$ & $11.58 \pm 0.24^{\mathrm{a}}$ \\
\hline Carbohydrate & $7.62 \pm 0.58^{\mathrm{a}}$ & $8.40 \pm 0.36^{\mathrm{a}}$ & $7.63 \pm 0.26^{\mathrm{a}}$ & $8.04 \pm 0.31^{\mathrm{a}}$ \\
\hline Ash & $2.88 \pm 0.02^{\mathrm{d}}$ & $3.12 \pm 0.00^{c}$ & $3.25 \pm 0.02^{\mathrm{b}}$ & $3.48 \pm 0.03^{\mathrm{a}}$ \\
\hline Energy value & $168^{\mathrm{b}}$ & $171^{\mathrm{b}}$ & $183^{\mathrm{a}}$ & $182^{\mathrm{a}}$ \\
\hline
\end{tabular}

${ }^{1}$ Values are given as mean \pm SD. Same letter within the same row indicates no significant difference. ${ }^{2} \mathrm{CT}-$ without addition of MDCM protein hydrolysate; T1 - $10 \%$ addition of MDCM protein hydrolysate; T2 - 20\% addition of MDCM protein hydrolysate; T3 - 30\% addition of MDCM protein hydrolysate. 
significantly lower $(\mathrm{P}<0.05)$ than that of the control samples (68.21\%). With regard to the protein content, the values were between 10.63 and $12.00 \%$. Protein content was higher in the treatments with protein hydrolysate, showing that the addition of protein hydrolysates can be an alternative to improve the protein content in meat products. However, the main advantage of the use of protein hydrolysates is not the increased protein levels but the changes in the protein characteristics that can be caused by hydrolysis. Fat values ranged from 10.41 and $11.71 \%$ with differences between the treatments. In meat products, the fat content depends on the amount added in the formulation. Thus, even with the differences between the treatments, all of the fat values found were quite similar to the fat level added to the formulation (10\%). In addition, the sausages with higher levels of MDCM protein hydrolysates showed higher levels of ash, and all treatments were different from each other $(\mathrm{P}<0.05)$. The energy values were between $168 \mathrm{kcal} / 100 \mathrm{~g}(\mathrm{CT})$ and $183 \mathrm{kcal} / 100 \mathrm{~g}$ (T2), and the addition of higher levels of MDCM protein hydrolysate (T2 and T3) significantly increased $(\mathrm{P}<0.05)$ these values as a consequence of the higher content of protein and fat in mortadella-type sausages.

\subsection{TBARS}

Lipid oxidation of mortadella-type sausages was affected by the MDCM addition $(\mathrm{P}<0.05$, Figure 1$)$ during storage. The average TBARS values ranged from 0.240 to $0.688 \mathrm{mg} \mathrm{MDA} /$ $\mathrm{kg}$ during storage. It should be observed that the treatment T3 showed higher lipid oxidation values since the first day of storage. It is likely that the temperature used during the hydrolysis process increased the MDCM lipid oxidation. Therefore, mortadella-type sausages with higher amounts of MDCM protein hydrolysates show higher TBARS values since the first day of storage. Furthermore, lipid and pigment oxidation is a common problem reported in the literature, especially in the case of meat protein hydrolysates (BuenoSolano et al., 2009; Klomklao et al., 2013).

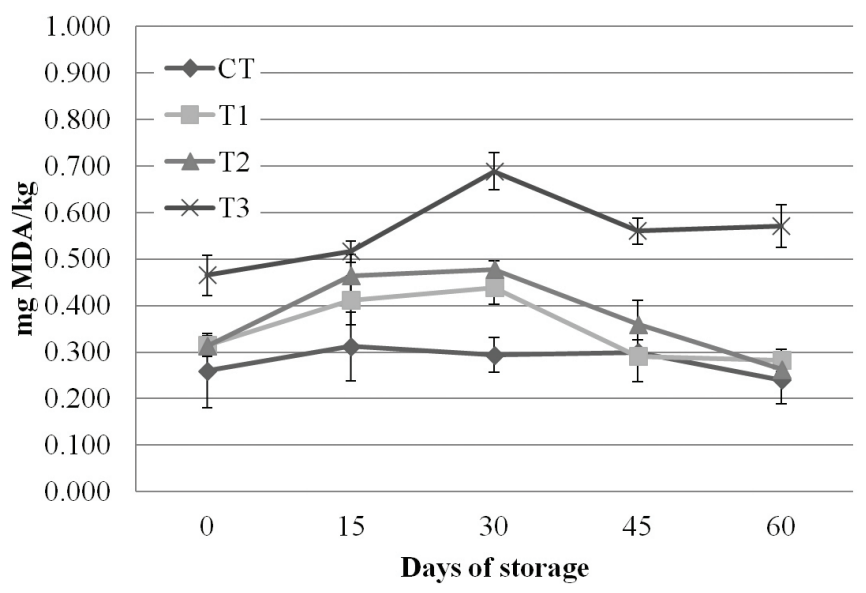

Figure 1. TBARS values of mortadella-type sausages produced with different levels of MDCM protein hydrolysates during storage. CT - without addition of MDCM protein hydrolysate; T1 - 10\% addition of MDCM protein hydrolysate; T2 - 20\% addition of MDCM protein hydrolysate; T3 - 30\% addition of MDCM protein hydrolysate.
The TBARS values of mortadella-type sausages with MDCM protein hydrolysate increased until the $30^{\text {th }}$ day of storage and decreased until the end of storage. According to Smith \& Alford (1968), some microorganisms can decompose MDA, and/or further oxidation of MDA in other compounds, such as alcohols and acids, which cannot react with the TBA test may occur (Fernández et al., 1997). This can be considered as a normal phenomenon, and some studies have already reported similar results in other meat products (Georgantelis et al., 2007; Kittiphattanabawon et al., 2012).

Overall, the mortadella-type sausages showed good oxidative stability during 60 days of storage (maximum TBARS value $=0.688 \mathrm{mg} \mathrm{MDA} / \mathrm{kg}$ ). According to $\mathrm{Wu}$ et al. (1991), when the TBARS value is higher than $1.0 \mathrm{mg} \mathrm{MDA} / \mathrm{kg}$, offodors are usually formed and it is considered as the beginning of organoleptic perception of lipid oxidation. Thus, taking this value as the rancidity detection threshold, it can be said that none of the treatments reached it until the $60^{\text {th }}$ day of storage.

Several studies have shown that protein hydrolysates have an important antioxidant capacity (Dong et al., 2008; Khantaphant et al., 2011; Klompong et al., 2007). The antioxidant properties of protein hydrolysates typically result from their capability to stabilize or terminate radicals, donate a hydrogen atom, and/or chelate pro-oxidative metal ions, including $\mathrm{Fe}^{2+}$ (Kittiphattanabawon et al., 2012). According to Raghavan \& Kristinsson (2008), the ability of different protein hydrolysates to chelate metal ions depends on the enzymes used in hydrolysis and the degree of hydrolysis of the hydrolysate. In order to obtain protein hydrolysates with better antioxidant capacity, it is necessary to apply methods that select and concentrate peptides that possess this function.

In meat model systems, Nasri et al. (2013) reported lower TBARS values in cooked turkey meat sausages added with different amounts of Goby (Zosterissessor ophiocephalus) fish protein hydrolysates $(0.01 \%, 0.02 \%, 0.04 \%$ and, $0.2 \%)$, when compared to those of the control samples. On day 3 of storage, all concentrations reduced meat lipid oxidation by more than $50 \%$ if compared to that of the control treatment. After the $12^{\text {th }}$ day of storage at $4{ }^{\circ} \mathrm{C}$, gradual decreases in TBARS values were also observed. Kittiphattanabawon et al. (2012) also reported that cooked comminuted pork meat with addition of higher levels of gelatin hydrolysate from blacktip shark (Carcharhinus limbatus) could inhibit lipid oxidation exhibiting lower TBARS values during storage. However, in this study, the synthetic antioxidant used showed a better preventive effect on lipid oxidation. Peña-Ramos \& Xiong (2003) and Wang \& Xiong (2005) could also inhibit lipid oxidation in cooked meat patties using soy and whey and potato hydrolysates, respectively. Since the antioxidant properties of protein hydrolysates depend on the raw material, the enzyme, and the degree of hydrolysis, further studies are needed to confirm that MDCM protein hydrolysates have peptides with antioxidant action. Some studies have already reported antioxidant activity in protein hydrolysates from chicken liver (Chou et al., 2014), chicken skin (Onuh et al., 2014), and chicken breast (Sun et al., 2012). Nevertheless, these studies were carried out using separation (centrifugation and ultrafiltration) and drying (lyophilization) methods for the protein hydrolysates. 


\subsection{Color measurements}

The addition of MDCM protein hydrolysates affected the color attributes of mortadella-type sausages (Table 2). As for the lightness $\left(L^{*}\right)$ index, the T3 means indicate that the products were darkest $(\mathrm{P}<0.05)$ at days 0 and 30 of storage. There is a negative correlation between lightness and the TBARS values (Hernández-Hernández et al., 2009). In other words, as oxidation increased, lightness decreased (the samples became darker). This relation was observed only at the days 0 and 30 of storage since T3 showed the lowest lightness values and higher TBARS values (Figure 1). The lightness values were between 63.36 and 58.66, with T2 lighter $(\mathrm{P}<0.05)$ than those of the other treatments in the end of storage. Moreover, there was a significant decrease in this index in the CT during storage, ranging from 63.04 (day 0) to 58.66 (day 60).

Mortadella-type sausages with no MDCM protein hydrolysates addition $(\mathrm{CT})$ had higher $(\mathrm{P}<0.05)$ redness $\left(a^{*}\right)$ during all days of storage. Nevertheless, the values at the end of storage were lower $(\mathrm{P}<0.05)$ than that at day 0 . The red color of mortadella-type sausages with MDCM protein hydrolysates addition was less intense than that of the CT, but it was more stable since there was no difference in the redness parameter between days 0 and 60 of storage. During the hydrolysis process, the hydrolysate can turn brownish yellow, probably due to the oxidation of myoglobin pigment of the meat (Benjakul \& Morrissey, 1997). The heat used during the hydrolysis process produced a prooxidant effect oxidizing the myoglobin to metmyoglobin, which is associated with a reduction in reddish color.

With regard to the yellowness parameter $\left(b^{*}\right)$, the CT showed more stable values when compared to the treatments with MDCM protein hydrolysate addition. There was no difference in the $b^{*}$ values between the beginning and the end of storage, while T1, T2, and, T3 had increased $b^{*}$ values $(\mathrm{P}<0.05)$ in the same period. An increase in these values may be related to a fading of the color of cured meats (American Meat Science Association, 1991), but, a decrease in $a^{\star}$ values would be necessary, which was not observed in the treatments with addition of MDCM protein hydrolysate.

Chroma $\left(C^{*}\right)$ and hue angle $\left(h^{\star}\right)$ are both based on $a^{*}$ and $b^{\star}$ values and, consequently, are influenced by both. The CT had a higher chroma and lower hue angle, indicating a more intense reddish color than that of the treatments containing MDCM protein hydrolysates. Another study also reported that myoglobin oxidation to brown metmyoglobin was associated with a reduction in reddish color in beef patties (SánchezEscalante et al., 2003).

\subsection{Texture profile analysis}

The addition of MDCM protein hydrolysates affected $(\mathrm{P}<0.05)$ the texture profile of mortadella-type sausages (Table 3). All parameters in the control treatment (CT) were higher than those of the other treatments with MDCM protein hydrolysate. Hardness values were lower in the products with

Table 2. Colorimetric parameters $\left(L^{*}, a^{*}, b^{*}, C^{*}\right.$, and $\left.h^{\circ}\right)$ of mortadella-type sausages produced with different levels of MDCM protein hydrolysates during storage. ${ }^{1}$

\begin{tabular}{|c|c|c|c|c|c|c|}
\hline \multirow{2}{*}{\multicolumn{2}{|c|}{ Treat. $^{2}$}} & \multicolumn{5}{|c|}{ Days of Storage } \\
\hline & & 0 & 15 & 30 & 45 & 60 \\
\hline \multirow{4}{*}{$L^{*}$} & $\mathrm{CT}$ & $63.04 \pm 1.59^{\mathrm{aA}}$ & $59.20 \pm 0.70^{\mathrm{bB}}$ & $58.98 \pm 1.39^{\mathrm{bA}}$ & $60.68 \pm 0.79^{\mathrm{abA}}$ & $58.66 \pm 1.26^{\mathrm{bB}}$ \\
\hline & $\mathrm{T} 1$ & $62.11 \pm 0.17^{\mathrm{abA}}$ & $62.73 \pm 1.15^{\mathrm{aA}}$ & $61.03 \pm 1.28^{\mathrm{abA}}$ & $60.56 \pm 1.25^{\mathrm{abA}}$ & $60.09 \pm 0.66^{\mathrm{bB}}$ \\
\hline & $\mathrm{T} 2$ & $61.16 \pm 0.97^{\mathrm{bA}}$ & $60.16 \pm 1.48^{\mathrm{bB}}$ & $59.86 \pm 0.55^{\mathrm{bA}}$ & $60.24 \pm 0.51^{\mathrm{bA}}$ & $63.36 \pm 1.20^{\mathrm{aA}}$ \\
\hline & T3 & $56.98 \pm 0.59^{\mathrm{cB}}$ & $59.40 \pm 0.57^{\mathrm{abB}}$ & $56.15 \pm 1.29^{\mathrm{cB}}$ & $60.56 \pm 1.14^{\mathrm{aA}}$ & $58.66 \pm 2.10^{\mathrm{abB}}$ \\
\hline \multirow{3}{*}{$a^{*}$} & $\mathrm{CT}$ & $23.18 \pm 0.27^{\mathrm{aA}}$ & $21.33 \pm 0.20^{\mathrm{cdA}}$ & $21.96 \pm 0.39^{\mathrm{bcA}}$ & $21.23 \pm 0.36^{\mathrm{dA}}$ & $22.15 \pm 0.22^{\mathrm{bA}}$ \\
\hline & $\mathrm{T} 1$ & $20.37 \pm 0.37^{\mathrm{aB}}$ & $20.55 \pm 0.41^{\mathrm{aA}}$ & $20.66 \pm 0.31^{\mathrm{aB}}$ & $20.14 \pm 0.51^{\mathrm{aB}}$ & $20.98 \pm 0.41^{\mathrm{aBC}}$ \\
\hline & $\mathrm{T} 2$ & $20.39 \pm 0.40^{\mathrm{abB}}$ & $19.29 \pm 0.41^{\mathrm{cdB}}$ & $20.10 \pm 0.62^{\mathrm{bcB}}$ & $18.93 \pm 0.28^{\mathrm{dC}}$ & $21.18 \pm 0.22^{\mathrm{aB}}$ \\
\hline \multirow{5}{*}{$b^{*}$} & $\mathrm{~T} 3$ & $20.43 \pm 0.50^{\mathrm{aB}}$ & $19.59 \pm 0.19^{\mathrm{aB}}$ & $19.96 \pm 0.51^{\mathrm{aB}}$ & $19.97 \pm 0.63^{\mathrm{aB}}$ & $20.35 \pm 0.61^{\mathrm{aC}}$ \\
\hline & CT & $13.50 \pm 0.21^{\mathrm{aA}}$ & $12.68 \pm 0.10^{\mathrm{bA}}$ & $13.13 \pm 0.23^{\mathrm{aA}}$ & $12.44 \pm 0.28^{\mathrm{bC}}$ & $13.50 \pm 0.08^{\mathrm{aBC}}$ \\
\hline & $\mathrm{T} 1$ & $11.79 \pm 0.13^{\mathrm{cC}}$ & $12.78 \pm 0.21^{\mathrm{bA}}$ & $12.81 \pm 0.22^{\mathrm{bA}}$ & $12.99 \pm 0.17^{\mathrm{abB}}$ & $13.27 \pm 0.26^{\mathrm{aC}}$ \\
\hline & $\mathrm{T} 2$ & $12.40 \pm 0.10^{\mathrm{cB}}$ & $12.40 \pm 0.23^{\mathrm{cA}}$ & $13.16 \pm 0.34^{\mathrm{bA}}$ & $12.90 \pm 0.19^{\mathrm{bB}}$ & $14.17 \pm 0.14^{\mathrm{aA}}$ \\
\hline & $\mathrm{T} 3$ & $11.59 \pm 0.23^{\mathrm{cC}}$ & $12.59 \pm 0.19^{\mathrm{bA}}$ & $13.24 \pm 0.19^{\mathrm{aA}}$ & $13.51 \pm 0.22^{\mathrm{aA}}$ & $13.60 \pm 0.09^{\mathrm{aB}}$ \\
\hline \multirow{3}{*}{$C^{*}$} & $\mathrm{CT}$ & $27.49 \pm 0.84^{\mathrm{aA}}$ & $24.81 \pm 0.22^{\mathrm{cdA}}$ & $25.58 \pm 0.42^{\mathrm{bcA}}$ & $24.60 \pm 0.45^{\mathrm{dA}}$ & $25.93 \pm 0.21^{\mathrm{bA}}$ \\
\hline & $\mathrm{T} 1$ & $23.53 \pm 0.38^{\mathrm{bB}}$ & $24.20 \pm 0.46^{\mathrm{abAB}}$ & $24.31 \pm 0.38^{\mathrm{abB}}$ & $23.96 \pm 0.51^{\mathrm{abA}}$ & $24.82 \pm 0.48^{\mathrm{bBC}}$ \\
\hline & $\mathrm{T} 2$ & $23.86 \pm 0.31^{\mathrm{bcB}}$ & $22.93 \pm 0.64^{\mathrm{cC}}$ & $24.02 \pm 0.70^{\mathrm{bB}}$ & $22.90 \pm 0.34^{\mathrm{cB}}$ & $25.48 \pm 0.17^{\mathrm{aAB}}$ \\
\hline \multirow{5}{*}{$h^{o}$} & $\mathrm{~T} 3$ & $23.48 \pm 0.54^{\mathrm{abB}}$ & $23.29 \pm 0.34^{\mathrm{bBC}}$ & $24.06 \pm 0.61^{\mathrm{abB}}$ & $24.10 \pm 0.64^{\mathrm{abA}}$ & $24.47 \pm 0.52^{\mathrm{aB}}$ \\
\hline & $\mathrm{CT}$ & $30.2 \pm 0.3^{\mathrm{cB}}$ & $30.7 \pm 0.1^{\mathrm{bcc}}$ & $30.9 \pm 0.4^{\mathrm{abC}}$ & $30.3 \pm 0.2^{\mathrm{bcc}}$ & $31.4 \pm 0.2^{\mathrm{aC}}$ \\
\hline & $\mathrm{T} 1$ & $30.0 \pm 0.2^{\mathrm{dB}}$ & $31.8 \pm 0.2^{\mathrm{bcB}}$ & $31.7 \pm 0.1^{\mathrm{cB}}$ & $32.8 \pm 0.4^{\mathrm{aB}}$ & $32.3 \pm 0.2^{\mathrm{abB}}$ \\
\hline & $\mathrm{T} 2$ & $31.3 \pm 0.7^{\mathrm{dA}}$ & $32.7 \pm 0.4^{\mathrm{cA}}$ & $33.2 \pm 0.2^{\mathrm{bcA}}$ & $34.3 \pm 0.2^{\mathrm{aA}}$ & $33.7 \pm 0.4^{\mathrm{abA}}$ \\
\hline & T3 & $29.5 \pm 0.2^{\mathrm{cB}}$ & $32.7 \pm 0.2^{\mathrm{bA}}$ & $33.5 \pm 0.4^{\mathrm{abA}}$ & $34.1 \pm 0.4^{\mathrm{aA}}$ & $33.7 \pm 0.8^{\mathrm{abA}}$ \\
\hline
\end{tabular}

${ }^{1}$ Values are given as mean \pm SD. Same letter within the same row indicates no significant difference. Same capital letter within the same column indicates no significant difference. ${ }^{2} \mathrm{CT}$ - without addition of MDCM protein hydrolysate; T1 - 10\% addition of MDCM protein hydrolysate; T2 - $20 \%$ addition of MDCM protein hydrolysate; T3 - 30\% addition of MDCM protein hydrolysate. 
more than $20 \%$ of MDCM protein hydrolysates when compared to those of the other treatments.

The treatment with addition of $10 \%$ of MDCM protein hydrolysate $(\mathrm{T} 1)$ had lower $(\mathrm{P}>0.05)$ hardness values than control treatment but higher $(\mathrm{P}>0.05)$ than $\mathrm{T} 2$ and $\mathrm{T} 3$. Springiness represents the extent of recovery of sausage height and, the values showed difference $(\mathrm{P}<0.05)$ as the addition of protein hydrolysate was increased in the sausages elaboration (Table 3). The secondary parameters of cohesiveness, gumminess and chewiness have similar results to those parameters, showing a decrease as the MDCM protein hydrolysate levels increased.

The results of the texture profile analysis were in accordance with those found by Sun et al.(2010), who observed a decrease in the texture parameters of Cantonese sausages due to the addition of Maillard reaction products derived from the mechanically deboned chicken residue hydrolysate. Lower values of hardness, gumminess, and chewiness of cooked meat sausages with the addition of MDCM protein hydrolysates may be associated with weaker internal structure of the MDCM protein hydrolysate than that of the MDCM in its traditional form.

\subsection{Microbiological analysis}

The microbiological characteristics of the mortadella-type sausages made with MDCM protein hydrolysates are shown in Table 4. All of the treatments had good microbiological quality during storage. The CT showed higher $(\mathrm{P}<0.05) \mathrm{TVC}$ counts but lower LAB counts at the end of storage (60 days). Furthermore, the mortadella-type sausages containing MDCM protein hydrolysates also had higher $(\mathrm{P}<0.05)$ LAB counts on days 15 and 45 of storage when compared to those of the CT.

Lazzi et al. (2011) showed that the addition of protein hydrolysate obtained from the poultry industry promoted the growth of a wide range of Bifidobacterium species of human origin. Recently, Lazzi et al. (2013) also reported that the growth of Lactobacillus species could also be improved by the supplementation with proteinaceous hydrolysates derived from poultry processing leftovers. These studies showed that protein hydrolysates from poultry meat are a promising functional food, and this is probably one of the reasons why the treatments with MDCM protein hydrolysate addition showed higher LAB counts when compared to those of the control treatment.

Zanello et al. (2014) have recently showed that poultry bone and meat trimming hydrolysates do not have in vitro antimicrobial activity against E. coli, Listeria monocytogenes, Lactobacillus sp., Pseudomonas sp., and Salmonella sp. However, the addition of $1.5 \%$ of protein hydrolysate to minced turkey meat could inhibit the microbial growth of mesophilic (TVC), psychrophilic, and Enteterobacteriaceae groups. In our study, the values of Enterobacteriaceae, E. coli, S. aureus, sulfite reducer clostridia, and Salmonella were not detected in all treatments (data not shown) during the entire storage period, and therefore these values are in accordance with the Brazilian legislation requirements (Brasil, 2001).

Table 3. Textural properties of mortadella-type sausages made with different levels of MDCM protein hydrolysates. ${ }^{1}$

\begin{tabular}{lrrrr}
\hline \multirow{2}{*}{ Parameters } & \multicolumn{3}{c}{ Treatments $^{2}$} \\
\cline { 2 - 5 } & \multicolumn{1}{c}{ CT } & T1 & T2 & $3.68 \pm 0.82^{\mathrm{c}}$ \\
\hline Hard (N) & $27.13 \pm 3.92^{\mathrm{a}}$ & $8.33 \pm 0.90^{\mathrm{b}}$ & $0.49 \pm 0.11^{\mathrm{c}}$ & $3.93 \pm 0.68^{\mathrm{c}}$ \\
Spring (mm) & $0.94 \pm 0.03^{\mathrm{a}}$ & $0.65 \pm 0.07^{\mathrm{b}}$ & $0.29 \pm 0.02^{\mathrm{c}}$ & $0.47 \pm 0.06^{\mathrm{c}}$ \\
Cohes (ratio) & $0.76 \pm 0.04^{\mathrm{a}}$ & $0.36 \pm 0.04^{\mathrm{b}}$ & $1.37 \pm 0.22^{\mathrm{b}}$ & $0.30 \pm 0.01^{\mathrm{c}}$ \\
Gumm (N) & $20.57 \pm 3.57^{\mathrm{a}}$ & $3.01 \pm 0.59^{\mathrm{b}}$ & $0.69 \pm 0.27^{\mathrm{b}}$ & $1.18 \pm 0.23^{\mathrm{b}}$ \\
Chew (Nmm) & $19.24 \pm 3.62^{\mathrm{a}}$ & $1.99 \pm 0.54^{\mathrm{b}}$ & $0.56 \pm 0.15^{\mathrm{b}}$ \\
\hline
\end{tabular}

${ }^{1}$ Values are given as mean \pm SD. Same letter in within the same row indicates no significant difference. ${ }^{2} \mathrm{CT}$ - without addition of MDCM protein hydrolysate; T1 - $10 \%$ addition of MDCM protein hydrolysate; T2 - 20\% addition of MDCM protein hydrolysate; T3 - 30\% addition of MDCM protein hydrolysate. Hard - Hardness; Spring - Springiness; Cohes - Cohesiveness; Gumm - Gumminess; Chew - Chewiness.

Table 4. Microbiological counts of mortadella-type sausages produced with different levels of MDCM protein hydrolysates. ${ }^{1}$

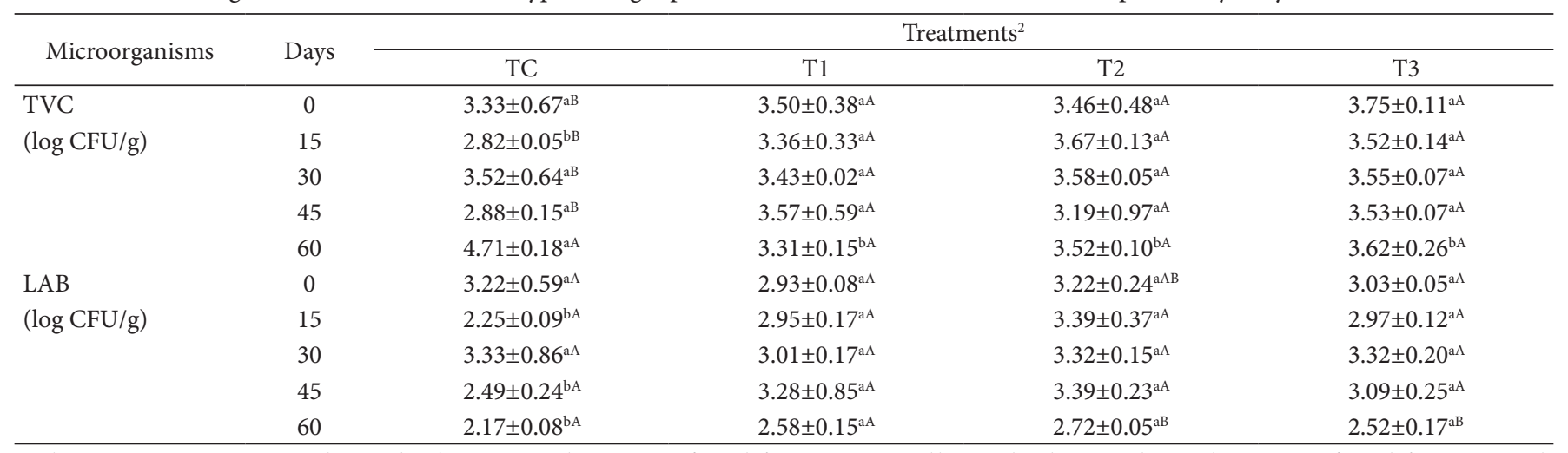

${ }^{1}$ Values are given as mean \pm SD. Same letter within the same row indicates no significant difference. Same capital letter within the same column indicates no significant difference. ${ }^{2}$ Control Treatment (CT) - without addition of MDCM protein hydrolysate; T1 - 10\% addition of MDCM protein hydrolysate; T2 - $20 \%$ addition of MDCM protein hydrolysate; T3 - 30\% addition of MDCM protein hydrolysate. TVC - Total viable counts; LAB - Lactic acid bacteria. 


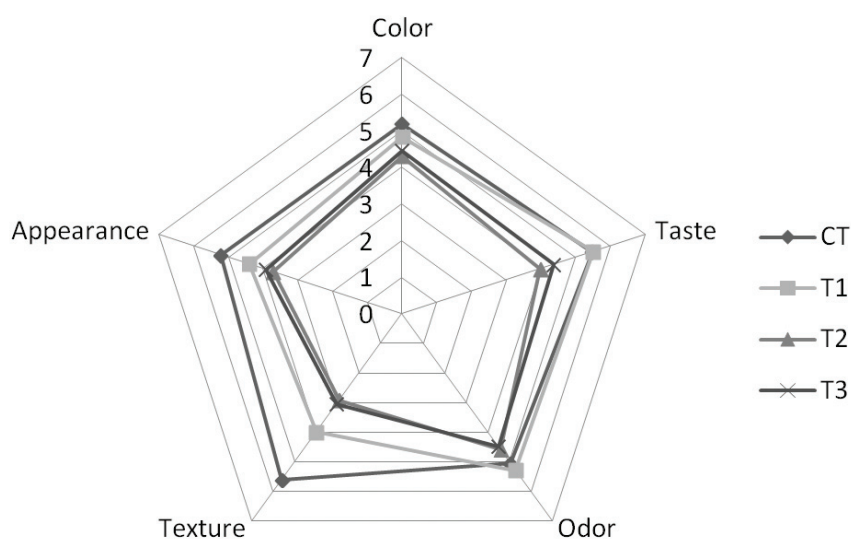

Figure 2. Sensory attributes of mortadella-type sausages produced with different levels of MDCM protein hydrolysates. CT - without addition of MDCM protein hydrolysate; T1 - 10\% addition of MDCM protein hydrolysate; T2 - 20\% addition of MDCM protein hydrolysate; T3 - 30\% addition of MDCM protein hydrolysate.

\subsection{Sensory evaluation}

The addition of increasing levels of MDCM proteinhydrolysates had a negative effect on the sensory parameters analyzed by the panelists (Figure 2). The CT obtained higher $(\mathrm{P}<0.05)$ scores for all attributes. The addition of more than $20 \%$ of MDCM protein hydrolysates affected the color, taste, and odor attributes of mortadella-type sausages. It is also known that the hydrolysis of protein produces peptides with brownish color and that the addition of large quantities of protein hydrolysate can affect the color of the product (Bueno-Solano et al., 2009). Moreover, other studies reported that the major disadvantage of the use of protein hydrolysates is the occurrence of bitter peptides (Spellman et al., 2009). It is likely that the bitter taste of these peptides can be experienced in the products and, therefore, this is the reason why T2 and T3 obtained lower scores $(\mathrm{P}<$ 0.05 ) for the taste parameter.

The panelists also reported that mortadella-type sausages with higher amounts of MDCM protein hydrolysate (T2 and T3) had softened texture, and consequently these treatments obtained lower scores $(\mathrm{P}<0.05)$ than those of the others. It is likely that the addition of higher quantities of protein hydrolysates can be more useful in meat products with soft texture, such as patties. The future purchase intention scores were between 2.37 and 4.16 (data not shown), and as expected, the CT had the highest values $(\mathrm{P}<0.05)$.

\section{Conclusions}

Based on the results of this study, it can be said that MDCM protein hydrolysate is a promising raw material for use in cooked meat products. However, the addition of more than $10 \%$ of MDCM protein hydrolysates to mortadella-type sausages affect lipid oxidation, color parameters, taste and texture, and, the addition of more than $10 \%$ of MDCM protein hydrolysate has not been recommended so far.

Further studies on different forms of MDCM protein hydrolysates and different meat products should be conducted.

\section{References}

American Meat Science Association - AMSA. (1991). Guidelines for meat color evaluation. In 44th Annual Reciprocal Meat Conference (pp. 3-17), Manhattan, Kansas. Chicago: National Livestock and Meat Board.

Association of Official Analytical Chemists - AOAC. (1997). Official methods of analysis. 15th ed. Washington.

Benjakul, S., \& Morrissey, M. T. (1997). Protein hydrolysates from Pacific Whiting Solid Wastes. Journal of Agricultural and Food Chemistry, 45(9), 3423-3430. http://dx.doi.org/10.1021/jf970294g

Bligh, E. G., \& Dyer, W. J. (1959). A rapid method of total lipid extraction and purification. Canadian Journal of Biochemical Physiology, 37(8), 911-917. http://dx.doi.org/10.1139/o59-099

Bourne, M. C. (1978). Texture profile analysis. Food Technology, 32(7), 62-66.

Brasil, Ministério da Agricultura e Abastecimento. Regulamento Técnico de Identidade e Qualidade de Mortadela (Instrução Normativa n. 4, de 31 de março de 2000). Diário Oficial da República Federativa do Brasil.

Brasil, Agência Nacional de Vigilância Sanitária - ANVISA. Regulamento técnico sobre padrões microbiológicos para alimentos (Resolução n. 12, de 2 de janeiro de 2001). Diário Oficial da República Federativa do Brasil.

Bueno-Solano, C., López-Cervantes, J., Campas-Baypoli, O. N., Lauterio-García, R., Adan-Bante, N. P., \& Sánchez-Machado, D. I. (2009). Chemical and biological characteristics of protein hydrolysates from fermented shrimp by-products. Food Chemistry, 112(3), 671-675. http://dx.doi.org/10.1016/j.foodchem.2008.06.029

Chou, C-H., Wang, S-Y., Lin, Y-T., \& Chen, Y-C. (2014). Antioxidant activities of chicken liver hydrolysates by pepsin treatment. International Journal of Food Science and Technology, 49(7), 16541662. http://dx.doi.org/10.1111/ijfs.12471

Contreras, M. D. M., Hernández-Ledesma, B., Amigo, L., MartínÁlvarez, P. J., \& Recio, I. (2011). Production of antioxidant hydrolyzates from a whey protein concentrate with thermolysin: optimization by response surface methodology. LWT - Food Science and Technology, 44(1), 9-15. http://dx.doi.org/10.1016/j. lwt.2010.06.017

Cumby, N., Zhong, Y., Naczk, M., \& Shahidi, F. (2008). Antioxidant activity and water-holding capacity of canola protein hydrolysates. Food Chemistry, 109(1), 144-148. http://dx.doi.org/10.1016/j. foodchem.2007.12.039

Dekkers, E., Raghavan, S., Kristinsson, H. G., \& Marshall, M. R. (2011). Oxidative stability of mahi mahi red muscle dipped in tilapia protein hydrolysates. Food Chemistry, 124(2), 640-645. http://dx.doi. org/10.1016/j.foodchem.2010.06.088

Dey, S. S., \& Dora, K. C. (2014). Optimization of the production of shrimp waste protein hydrolysate using microbial proteases adopting response surface methodology. Journal of Food Science and Technology, 51(1), 16-24. PMid:24426043. http://dx.doi. org/10.1007/s13197-011-0455-4

Dong, S., Zeng, M., Wang, D., Liu, Z., Zhao, Y., \& Yang, H. (2008). Antioxidant and biochemical properties of protein hydrolysates prepared from Silver carp (Hypophthalmichthys molitrix). Food Chemistry, 107(4), 1485-1493. http://dx.doi.org/10.1016/j. foodchem.2007.10.011

Fernández, J., Pérez-Álvarez, J. A., \& Fernández-López, J. A. (1997). Thiobarbituric acid test for monitoring lipid oxidation in meat. Food Chemistry, 59(3), 345-353. http://dx.doi.org/10.1016/S03088146(96)00114-8 
Georgantelis, D., Ambrosiadis, I., Katikou, P., Blekas, G., \& Georgakis, S. A. (2007). Effect of rosemary extract, chitosan and a-tocopherol on microbiological parameters and lipid oxidation of fresh pork sausage stored at $4^{\circ} \mathrm{C}$. Meat Science, 76(1), 172-181. PMid:22064204. http://dx.doi.org/10.1016/j.meatsci.2006.10.026

Hernández-Hernández, E., Ponce-Alquicira, E., Jaramillo-Flores, M. E., \& Guerrero Legarret, I. (2009). Antioxidant effect of Rosemary (Rosmarinus officinalis L.) and oregano (Origanum vulgare L.) extracts on TBARS and colour of model raw pork batters. Meat Science, 81(2), 410-417. PMid:22064182. http://dx.doi.org/10.1016/j. meatsci.2008.09.004

Hoyle, N. T., \& Merritt, J. N. (1994). Quality of fish protein hydrolysates from Herring (Clupea harengus). Journal of Food Science, 59(1), 7679. http://dx.doi.org/10.1111/j.1365-2621.1994.tb06901.x

Kannan, A., Hettiarachchy, N. S., Marshall, M., Raghavan, S., \& Kristinsson, H. (2011). Shrimp shell peptide hydrolysates inhibit human cancer cell proliferation. Journal of the Science of Food and Agriculture, 91(10), 1920-1924. PMid:21594874. http://dx.doi. org/10.1002/jsfa.4464

Khantaphant, S., Benjakul, S., \& Ghomi, M. R. (2011). The effects of pretreatments on antioxidative activities of protein hydrolysate from the muscle of brownstripe red snapper (Lutjanus vita). LWT - Food Science and Technology, 44(4), 1139-1148. http://dx.doi. org/10.1016/j.lwt.2010.10.009

Kittiphattanabawon, P., Benjakul, S., Visessanguan, W., \& Shahidi, F. (2012). Gelatin hydrolysate from blacktip shark skin prepared using papaya latex enzyme: antioxidant activity and its potential in model systems. Food Chemistry, 135(3), 1118-1126. PMid:22953833. http:// dx.doi.org/10.1016/j.foodchem.2012.05.080

Klomklao, S., Kishimura, H., \& Benjakul, S. (2013). Use of viscera extract from hybrid catfish (Clarias macrocephalus x Clarias gariepinus) for the production of protein hydrolysates from toothed ponyfish (Gazza minuta) muscle. Food Chemistry, 136(2), 1006-1012. PMid:23122156. http://dx.doi.org/10.1016/j. foodchem.2012.09.037

Klompong, V., Benjakul, S., Kantachote, D., \& Shahidi, F. (2007). Antioxidative activity and functional properties of protein hydrolysates of yellow stripe trevally (Selaroides leptolepis) as influenced by the degree of hydrolysis and enzyme type. Food Chemistry, 102(4), 1317-1327. http://dx.doi.org/10.1016/j. foodchem.2006.07.016

Lazzi, C., Meli, F., Dossena, A., Gatti, M., \& Neviani, E. (2011). Growth promotion of Bifidobacterium species by poultry bone and meat trimming hydrolyzate. Journal of Food Science, 76(6), 392-397. PMid:21623787. http://dx.doi.org/10.1111/j.17503841.2011.02212.x

Lazzi, C., Meli, F., Lambertini, F., Bottesini, C., Nikolaev, I., Gatti, M., Sforza, S., Koroleva. O., Popov, V., Neviani, E., \& Dossena, A. (2013). Growth promotion of Bifidobacterium and Lactobacillus species by proteinaceous hydrolysates derived from poultry processing leftovers. International Journal of Food Science and Technology, 48(2), 341-349. http://dx.doi.org/10.1111/j.1365-2621.2012.03192.x

Meilgaard, M., Civille, G. V., \& Carr, B. T. (1999). Sensory evaluation techniques. 3rd ed. CRC Press. http://dx.doi. org/10.1201/9781439832271

Mielnik, M. B., Aaby, K., Rolfsen, K., Ellekjær, M. R., \& Nilsson, A. (2002). Quality of comminuted sausages formulated from mechanically deboned poultry meat. Meat Science, 61(1), 73-84. http://dx.doi.org/10.1016/S0309-1740(01)00167-X

Nasri, R., Younes, I., Jridi, M., Trigui, M., Bougatef, A., Nedjar Arroume, N., Dhulster, P., Nasri, M., \& Karra-Chaabouni, M. (2013). ACE inhibitory and antioxidative activities of Goby (Zosterissessor opiocephalus) fish protein hydrolysates: effect on meat lipid oxidation. Food Research International, 54(1), 552-561. http://dx.doi. org/10.1016/j.foodres.2013.07.001

Onuh, J. O., Girgih, A. T., Aluko, R. E., \& Aliani, M. (2014). In vitro antioxidant properties of chicken skin enzymatic protein hydrolysates and membrane fractions. Food Chemistry, 150, 366-373. PMid:24360464. http://dx.doi.org/10.1016/j.foodchem.2013.10.107

Peña-Ramos, E. A., \& Xiong, Y. L. (2003). Whey and soy protein hydrolysates inhibit lipid oxidation in cooked pork patties. Meat Science, 64(3), 259-263. http://dx.doi.org/10.1016/S03091740(02)00187-0

Raghavan, S., \& Kristinsson, H. G. (2008). Antioxidative efficacy of alkali-treated tilapia protein hydrolysates: a comparison study of five enzymes. Journal of Agricultural and Food Chemistry, 56(4), 1434-1441. PMid:18247531. http://dx.doi.org/10.1021/jf0733160

Raharjo, S., Sofos, J. N., \& Schmidt, G. R. (1992). Improved speed, specificity, and limit of determination of an aqueous acid extraction thiobarbituric acid-C18 method for measuring lipid peroxidation in beef. Journal of Agricultural and Food Chemistry, 40(11), 21822185. http://dx.doi.org/10.1021/jf00023a027

Sánchez-Escalante, A., Djenane, D., Torrescano, G., Beltrán, J. A., \& Roncales, P. (2003). Antioxidant action of borage, rosemary, oregano and ascorbic acid in beef patties packaged in modified atmosphere. Journal of Food Science, 68(1), 339-344. http://dx.doi. org/10.1111/j.1365-2621.2003.tb14162.x

Smith, J. L., \& Alford, J. A. (1968). Action of microorganisms on the peroxides and carbonyls of rancid fat. Journal of Food Science, 33(1), 93-97. http://dx.doi.org/10.1111/j.1365-2621.1968.tb00891.x

Spellman, D., O’Cuinn, G., \& Fitzgerald, R. J. (2009). Bitterness in Bacillus proteinase hydrolysates of whey proteins. Food Chemistry, 114(2), 440-446. http://dx.doi.org/10.1016/j.foodchem.2008.09.067

Sun, W., Zhao, M., Cui, C., Zhao, Q., \& Yang, B. (2010). Effect of Maillard reaction products derived from the hydrolysate of mechanically deboned chicken residue on the antioxidant, textural and sensory properties of Cantonese sausages. Meat Science, 86(2), 276-282. PMid:20510531. http://dx.doi.org/10.1016/j.meatsci.2010.04.014

Sun, Y., Pan, D., Guo, Y., \& Li, J. (2012). Purification of chicken breast protein hydrolysates and analysis of its antioxidant activity. Food and Chemical Toxicology, 50(10), 3397-3404. PMid:22871395. http:// dx.doi.org/10.1016/j.fct.2012.07.047

Vanderzant, C., \& Splittstoesser, D. F. (1992). Compendium of methods for the microbiological examination of foods. Washington: APHA. PMid:22059567.

Wang, L. L., \& Xiong, Y. L. (2005). Inhibition of lipid oxidation in cooked beef patties by hydrolyzed potato protein is related to its reducing and radical scavenging ability. Journal of Agricultural and Food Chemistry, 53(23), 9186-9192. PMid:16277421. http://dx.doi. org/10.1021/jf051213g

Wu, W. H., Rule, D. C., Busboom, J. R., Field, R. A. \& Ray, B. (1991) Starter culture and time/temperature of storage influences on quality of fermented mutton sausage. Journal of Food Science, 56(4), 916919. http://dx.doi.org/10.1111/j.1365-2621.1991.tb14605.x

Zanello, P. P., Sforza, S., Dossena, A., Lambertini, F., Bottesini, C., Nikolaev, I. V., Koroleva, O., Ciociola, T., Magliani, W., Conti, S., \& Polonellia, L. (2014). Antimicrobial activity of poultry bone and meat trimmings hydrolyzates in low-sodium turkey food. Food and Function, 5(2), 220-228. PMid:24284558. http://dx.doi.org/10.1039/ c3fo60454c 